УДК 343.13

DOI https://doi.org/10.32849/2663-5313/2019.10.29

\title{
о. Дудко,
}

аспірант наукової лабораторії з проблем протидії злочинності

Навчально-наукового інституту № 1

Національної академії внутрішніх справ

\section{ПОМИЛКИ АДВОКАТА ПІД ЧАС ПРОВЕДЕННЯ ДОПИТУ НА СТАДІЇ ДОСУДОВОГО РОЗСЛІДУВАННЯ}

У науковій статті акиентовано увагу на ролі і місиі адвоката під час допиту свідка, висвітлено тактико-організачійні особливості його діяльності, спрямовані на підготовку до допиту свідка та на участь в отриманні його показань на стадії досудового розслідування. Виокремлено окремі причини неналежного рівня надання правової допомоги, сформульовано пропозиії щодо покращення діяльності адвоката у ивому напрямі. Визначено, що вироблена адвокатом та його клієнтом позиція у кримінальному провадженні повинна бути спрямована на мінімізацію можливих ризиків для допитуваного, у зв'язку з чим у процесі підготовки адвокат ставить себе на місие слідчого, вишукуючи в його позиції слабкі моменти, після чого пояснює їх клієнтові. З'ясовано, що під час вироблення спільної позиції і одночасного консультування клієнта адвокат повинен передбачити будь-які варіанти розвитку допиту, ретельно обговорити їх з клієнтом, щоб той був готовий дати чіткі відповіді на будь-яке питання слідчого і відреагував на дії останнього саме таким чином, як заплановано на підготовчій стадії. Доведено, що наявність у адвоката та у свідка письмового тексту показань має надзвичайно важливе значення, оскільки надалі, у разі повторного виклику свідка на допит, а тим більше можливого притягнення його до кримінальної відповідальності у иьому кримінальному провадженні, даний документ значно полегшить підготовку до допиту у статусі підозрюваного, обвинуваченого. Наголошено на значному обсязі завдань, які повинен для себе ставити і в подальшому вирішувати для свого довірителя адвокат, що свідчить про значимість виконуваної роботи для клієнта у кримінальному провадженні. Надзвичайно важливим при иьому є знання та вміле застосування адвокатом тактичних прийомів, спрямованих на встановлення належного контакту не тільки з підзахисним, а й з уповноваженою особою, яка проводить вказану слідчу (розшукову) дію. Зроблено висновок про важливість фактичних даних, отриманих шляхом допиту свідка під час досудового розслідування, за допомогою яких визначаються напрями подальшого розслідування, з'ясовуються окремі факти про подію та інші обставини кримінального правопорушення, характер дій кожного співучасника, дані, що мають тактичне значення тощо.

Ключові слова: досудове розслідування, допит свідка, показання, адвокат, клопотання, тактичні прийоми.

Постановка проблеми. Одним з основних та найпоширеніших джерел доказів у кримінальному провадженні є показання свідка. Зміни вітчизняного кримінального процесуального законодавства на сучасному етапі, пов’язані з набуттям законної сили КПК України 2012 р. та Законом України від 5 липня 2012 р. «Про адвокатуру та адвокатську діяльність», істотно вплинули на правове регулювання отримання показань свідків і гарантування дотримання їхніх прав та законних інтересів. Забезпечення зазначеним особам можливості реалізації своїх процесуальних прав і обов'язків - надзвичайно важливе завдання державних органів і посадових осіб, які здійснюють кримінальне провадження.

Зауважимо, що участь адвоката в окремих слідчих (розшукових) діях, які проводяться
3 учасником кримінального провадження з ініціативи слідчого, прокурора або за клопотанням адвоката, є очевидним та істотним елементом змісту тактики захисту та представництва. Звернемо увагу, що це елемент не слідчої тактики, а саме тактики діяльності адвоката, бо вивчатися і розроблятися ці питання повинні стосовно діяльності адвоката, а не сторони обвинувачення, професійні інтереси якої часто протилежні інтересам адвоката, насамперед захисника.

Найбільш рельєфно проблема діяльності адвоката, залученого до участі у кримінальному провадженні, проявляється саме у досудовому провадженні [1]. Сказане передбачає необхідність розробки практичних рекомендацій тактичного характеру у діяльності адвоката, залученого до участі у проведенні 
допиту, яким, на жаль, з моменту набуття чинності КПК України не приділено належної уваги.

Аналіз останніх досліджень. Значний внесок у розробку загальнотеоретичних і процесуальних засад проведення слідчих (розшукових) дій за участю свідків, визначення тактики їх проведення здійснили такі криміналісти й процесуалісти як В. П. Бахін, Т. В. Варфоломєєва, В. К. Весельський, А. Ф. Волобуєв, В. Г. Гончаренко, М. І. Гошовський, Ю. М. Грошевий, А. В. Іщенко, О. П. Кучинська, В. В. Лисенко, О. Р. Михайленко, М. А. Погорецький, С. М. Стахівський, М. С. Строгович, В. М. Тертишник, С. С. Чернявський, В. Ю. Шепітько, М. Є. Шумило, О. Г. Яновська та ін.

Як засвідчує слідча практика, допит свідка під час досудового розслідування супроводжується численними недоліками організаційного, тактичного та процесуального характеру, викликаних недостатнім професіоналізмом слідчого, прокурора, а також адвоката, залученого до проведення цієї слідчої (розшукової) дії. Констатуємо й відсутність методичних рекомендацій щодо тактичних прийомів, які повинен застосовувати адвокат під час допиту свідка, інтереси якого він представляє. Не досить кваліфікована, а подекуди безініціативна діяльність адвоката спричиняє негативні наслідки для клієнта у реалізації своїх прав та законних інтересів у кримінальному провадженні.

Мета дослідження. Враховуючи наукові здобутки щодо тактики проведення допиту під час досудового розслідування, дослідимо особливості участі адвоката у проведенні цієї слідчої (розшукової) дії, вкажемо на типові помилки, що спричиняють негативні наслідки для його клієнта, запропонуємо шляхи їх недопущення та усунення кримінальними процесуальними засобами.

Виклад основного матеріалу. Немає сумнівів, що сама присутність адвоката під час проведення слідчих (розшукових) дій найістотнішим чином впливає на тактичні можливості слідчого з успішного досягнення цілей, які перед ним стоять [2, с. 312-319]. Водночас особа, інтереси якої представляються, розраховує на якісну, професійну роботу адвоката у кримінальному провадженні. Участь адвоката-захисника є доцільною у слідчих (розшукових) діях, у проведенні яких сторона обвинувачення нерідко не дотримується рекомендації криміналістики і допускає процесуальні порушення, котрі не отримують відображення у протоколі слідчої (розшукової) дії (залишаються латентними) [3, с. 125]. y таких випадках адвокат-захисник іноді є єдиною процесуальною фігурою, яка може виявити зазначені порушення в ході слідчої (розшукової) дії, а надалі порушити питання про визнання отриманих доказів недопустимими (ст. 87 КПК) [4].

Важливість участі адвоката у проведенні допиту продиктована й тим, що, з одного боку, він надає правову допомогу клієнту, а з іншого - забезпечує додержання вимог КПК України щодо порядку проведення цієї слідчої (розшукової) дії та підвищує ефективність отримання допустимих та належних доказів. Адже його активність, кваліфікація та досвід здатні впливати на поведінку слідчого, а відповідні зауваження, заперечення, клопотання, пропозиції - на методику й тактику проведення слідчої (розшукової) дії, а отже, і на їі результат [5, с. 102].

Для реалізації зазначеної мети захисник наділяється сукупністю процесуальних прав, які надають йому можливість належним чином здійснювати доказування у кримінальному провадженні: бути присутнім на допитах підозрюваного, а також під час проведення інших процесуальних дій, що здійснюються з його участю або за клопотанням підозрюваного; з дозволу слідчого брати участь в інших слідчих (розшукових) діях; заявляти клопотання про проведення відповідних слідчих (розшукових) дій та брати в них участь; ставити питання, висловлювати свої пропозиції, зауваження та заперечення щодо порядку проведення відповідної слідчої (розшукової) дії, які заносяться до протоколу; використовувати науково-технічні засоби під час проведення слідчих (розшукових) дій тощо [5, с. 102].

На жаль, не всі адвокати належну увагу приділяють участі у допиті свідка, а окремі зовсім скептично ставляться до значущості його супроводу на допит: адже основну роботу виконує особа, яка здійснює допит, а до функції адвоката кримінальне процесуальне законодавство в цій частині підходить вкрай обмежено, відводячи їм незначний обсяг прав. Певна недовіра до необхідності запрошення на допит адвоката $є$ й у потенційних довірителів: адже свідку буцімто нічого не загрожує, його завдання - лише правдиво відповідати на запитання слідчого. 3 цієї причини, а також через те, що юридична допомога свідку часто має разовий характер, а отже, гонорар за таку роботу навряд чи може забезпечити адвоката матеріально на тривалий термін, брак уваги до процедури підготовки свідка до допиту й участі в самому допиті породжуе негативні наслідки для клієнта, деякі з яких вирішити буває неможливо або практично неможливо. 
Як показали результати узагальнення кримінальних проваджень, адвокати не завжди усвідомлюють тактичну значимість своєї участі у допиті свідка. Хоча важко переоцінити значущість для адвокатів та їх довірителів знань і вмінь застосувати розроблені криміналістикою і судовою психологією тактичні прийоми допиту. Навіть відведені слідчим питання захисника, задані ним в ході допиту на досудовому розслідуванні, можуть бути ефективною формою законної протидії обвинувальній діяльності слідчого, прокуpopa [3, c. 133].

Що стосується потенційних ризиків, які загрожують свідку у зв'язку з допитом, то поряд 3 очевидними, пов'язаними 3 можливим притягненням до кримінальної відповідальності за відмову від дачі показань і дачу завідомо неправдивих показань, часто $€$ й ризики подальшого затримання або повідомлення про підозру у кримінальному провадженні, в якому проводиться первинний допит у статусі свідка. Найчастіше такі ситуації виникають у разі розслідування кримінальних правопорушень у сфері економіки, розпочатих за фактом вчинення кримінального правопорушення, а не щодо конкретних осіб. У зв'язку з цим видається, що до таких ризиків можна ставитися поверхнево, а тому роль адвоката, тих рекомендацій, які він дає, і захисних заходів, які здійснюються у зв’язку з викликом на допит, вкрай висока.

Безумовно, будь-яка особа, звертаючись до адвоката за юридичною допомогою, має певну мету. При цьому цілі звертання можуть бути явними, тобто такими, які довіритель може для себе чітко сформулювати, а можуть бути прихованими, тобто такими, які йому з урахуванням наявного досвіду, допомагає сформулювати адвокат.

Безвідносно до статусу учасника кримінального провадження сформулюємо завдання, які вирішує для свого довірителя адвокат у зв'язку з участю в допиті під час досудового розслідування: початковий юридичний аналіз ситуації, у зв'язку з якою, на думку довірителя, він викликаний на допит; оцінка ризиків можливого притягнення до кримінальної відповідальності стосовно даної ситуації, а також можливого притягнення до кримінальної відповідальності близьких та рідних довірителя; рекомендації щодо мінімізації наявних ризиків, допомога у формуванні позиції для допиту; роз'яснення порядку проведення слідчої (розшукової) дії, наявних у клієнта прав, опис кожного з можливих варіантів розвитку ситуації під час допиту; забезпечення психологічного спокою до початку і в процесі проведення слідчої (розшукової) дії; забез- печення дотримання прав клієнта безпосередньо під час допиту, виключення фактів чинення на нього тиску, застосування незаконних форм впливу 3 метою отримання вигідних слідчому, прокуророві показань; встановлення робочого контакту зі слідчим, прокурором 3 метою отримання додаткової інформації про обставини кримінального провадження і його подальші перспективи для довірителя; отримання копії протоколу допиту та надання клієнту; аналіз ситуації за результатами допиту, роз'яснення довірителю можливих ризиків і перспектив кримінального провадження; рекомендації за результатами допиту щодо можливої мінімізації ризиків.

За спостереженнями окремих науковців та практиків, процес підготовки до проведення допиту повинен як мінімум у 2-3 рази перевищувати час проведення самої слідчої (розшукової) дії [7]. Звичайно, тривалість підготовчих дій залежить від багатьох об'єктивних та суб'єктивних чинників. Однак зрозуміло одне: така підготовка необхідна, i чим ретельнішою вона є, тим меншою $€$ ймовірність помилок, насамперед тактичного характеру.

Підготовка до допиту починається з первинної бесіди з довірителем, у якого слід 3'ясувати: хто і яким чином викликав його на допит? чи було йому призначено точний час? чи знає він, по якій справі й у зв’язку з якими обставинами його викликали на допит? що йому відомо про обставини кримінального провадження, чи притягнуто до відповідальності когось із його знайомих, чи допитувався хтось ще у кримінальному провадженні і яку позицію займав? чи бачить він сам для себе будь-які ризики у зв'язку з цим кримінальним провадженням? якщо так, то які саме? чи допитували його у даному кримінальному провадженні раніше? якщо так, то які він давав показання? чи опитували його оперативні співробітники? якщо так, то які давалися пояснення? чи проводилися стосовно нього будь-які інші слідчі (розшукові) дії, які ОРЗ? чи є у нього які-небудь документи або інші матеріальні свідчення (фотографії, малюнки, аудіо- відеозаписи і т. ін.), що підтверджують його позицію у кримінальному провадженні? у разі наявності, на думку довірителя, можливих ризиків притягнення до кримінальної відповідальності які відомості і докази може мати у своєму розпорядженні слідчий для таких висновків?

Знання та вміння застосовувати тактичні прийоми, спрямовані на встановлення належного контакту зі співрозмовником і на отримання від нього детальної інформації, що має значення для захисту, неоціненні при 
спілкуванні адвоката-захисника зі своїм підзахисним. Зокрема, в ході спілкування з клієнтом, який через різні обставини не може (хоча прагне до цього) повідомити адвокату інформацію, яка має значення для захисту його прав та законних інтересів, адвокат може застосовувати такі тактичні прийоми, розроблені криміналістикою і судовою психологією: створення сприятливих умов для продуктивного прояву психічних здібностей підзахисного (наприклад, проведення попередньої бесіди на теми, не пов'язані 3 кримінальним провадженням, але особисто значущі для підзахисного); переконання підзахисного в заінтересованості адвокатазахисника в його долі (підзахисний повинен бачити і відчувати увагу адвоката); постановка питань, що належать не до шуканого, а до суміжних з ним фактів (пригадування одного факту може спричинити за собою пригадування пов'язаних із ним фактів - попередніх, супутніх, наступних або подібних чи контрастуючих з ним); пропозиція викласти факти, суворо дотримуючись послідовності розвитку події, яка стала предметом розслідування; постановка уточнюючих запитань на кшталт: «а чому?», «а що було далі?», відповіді на які можуть пояснити психологічну динаміку розвитку події, його причини, мотиви і приводи; уникнення питань в негативній формі (не могли б ви пригадати), граматично складних питань; стимулювання спогадів на основі запропонованої підзахисному можливості порівняння будь-яких протилежних ознак, відмінностей або подібностей кількох об'єктів, про які даються показання; складання схем, планів місця події з наступною пропозицією підзахисному вказати на них своє місцезнаходження і дії в момент вчинення діяння, що стало предметом розслідування; вихід на місце події з підзахисним (який не перебуває під вартою) для отримання додаткової інформації про подію, що відбулася, на основі пожвавлення асоціацій $[8$, с. 108]

На практиці адвокат здебільшого стикається із ситуацією (82 \% вивчених кримінальних проваджень), коли клієнту відомо, у зв'язку з якими обставинами його викликають на допит, і він досить чітко може сформулювати власну позицію щодо цих обставин.

Перед допитом адвокат обов'язково повинен з'ясувати обставини, що становлять предмет доказування у кримінальному провадженні: подію кримінального правопорушення (час, місце, спосіб та інші обставини вчинення кримінального правопорушення, визначені ч. 1 ст. 91 КПК), а також ставлення до них довірителя. Вироблена адвокатом та його клієнтом позиція у кримінальному провадженні повинна бути спрямована на мінімізацію можливих ризиків для допитуваного, у зв'язку з чим у процесі підготовки адвокат ставить себе на місце слідчого, вишукуючи в його позиції слабкі моменти, після чого пояснює їх клієнтові.

Трапляється, що ряд моментів, навпаки, краще обійти і не згадувати. Це робиться в тому разі, коли можлива відповідь на питання несе в собі ризики спростування всієї позиції (а іншої відповіді довіритель запропонувати не може), може будь-яким іншим чином зашкодити підзахисному або іншій особі, якій той нашкодити б не хотів. У таких випадках адвокат обумовлює разом зі свідком відповіді на питання, які несуть у собі ризик, виходячи з інтересів свідка і припущень про те, що слідчий може дане питання і не поставити як через недостатню підготовку до допиту, так і через відсутність у кримінальному провадженні інформації, що породить такі питання. При цьому довірителю мають бути надані рекомендації про те, якої позиції йому слід дотримуватися, якщо такі питання будуть поставлені. Такі дії в інтересах клієнта в жодному разі не слід ототожнювати з помилкою.

Таким чином, під час вироблення спільної позиції і одночасного консультування клієнта адвокат повинен передбачити будьякі варіанти розвитку допиту, ретельно обговорити їх з клієнтом, щоб той був готовий дати чіткі відповіді на будь-яке питання слідчого і відреагував на дії останнього саме таким чином, як заплановано на підготовчій стадії.

Проте не завжди трапляються ситуації, коли довіритель може сформулювати, у зв'язку з якими обставинами його викликають на допит, а адвокат має можливість провести якісну підготовку. У 18 \% вивчених нами кримінальних проваджень довіритель взагалі не володів будь-якою інформацією про майбутній допит і не міг сформулювати своє ставлення до ситуації, у зв'язку з якою його допитуватимуть. $\mathrm{y}$ таких випадках адвокати часто вдаються до такого тактичного прийому, як зайнятість, наполягаючи на перенесенні слідчої (розшукової) дії на іншу дату (або час). При цьому вони намагаються зрозуміти причину виклику, а також настрій слідчого, прокурора щодо викликаного на допит клієнта.

Тактичний прийом спроби перенесення адвокатом допиту на іншу дату під приводом зайнятості, крім отримання інформації про мету допиту і настрої слідчого, дозволяе спробувати встановити 3 ним психологічний контакт, взяти ситуацію у свої руки, встановити не пасивну, а активну роль адвоката 
у подальшому проведенні слідчої (розшукової) дії, i, нарешті, дещо убезпечити довірителя від можливого затримання. У таких випадках помилкою адвоката буде радше його пасивність, аніж спроба, не виходячи за межі своїх повноважень, здійснити певні дії в інтересах довірителя, навіть усупереч інтересам правосуддя.

Досліджуючи проблеми тактики адвокатської діяльності, О.М. Баєв обгрунтовано зазначає, що до питання про участь адвоката у слідчій (розшуковій) дії слід підходити з особливою обережністю [2, с. 7-8]. Насамперед, адвокат повинен визначити, чи не зашкодить його участь у певній слідчій (розшуковій) дії оптимальній реалізації функції захисту надалі. Слід враховувати, що слідчі нерідко вбачають в адвокаті, що бере участь у проведенні слідчої (розшукової) дії, своєрідного понятого, який своєю присутністю засвідчує факт, результати і об'єктивність слідчої (розшукової) дії.

Адвокат свідка не є повноцінним учасником допиту, проте його присутність під час проведення цієї слідчої (розшукової) дії аж ніяк не даремна. Передусім він підтримуе свідка психологічно і запобігає порушенням $з$ боку слідчого. Крім того, правильна підготовка свідка й присутність адвоката на допиті - гарантії того, що свідок себе не обмовить [6, с. 127]. Водночас, на нашу думку, з тактичної точки зору адвокатзахисник повинен обговорити 3 клієнтом доцільність своєї участі у зазначеній слідчій (розшуковій) дії, адже неявка адвоката не перешкоджає проведенню допиту свідка у визначений слідчим час.

Безпосередньо під час допиту свідка адвокат має право: бути присутнім під час проведення цієї слідчої (розшукової) дії, надавати клієнту короткі консультації в присутності слідчого; для уточнення і доповнення відповідей ставити з дозволу слідчого запитання, що підлягають занесенню до протоколу; висловлювати заперечення проти порушень прав та законних інтересів довірителя; застосовувати з дозволу слідчого технічні засоби; знайомитися з протоколом допиту; оскаржувати рішення, дії чи бездіяльність слідчого в порядку, встановленому КПК.

Необхідно враховувати, що одним з основних завдань адвоката, крім самого контролю за правильністю фіксації показань допитуваного і дотриманням його прав, є отримання додаткової інформації для аналізу, а це можливо лише за умови встановлення психологічного контакту зі слідчим. Погоджуємось, що адвокату бажано уникати будь-яких конфліктних ситуацій та згладжувати їх, адже вони періодично виникають у ході допитів, проте в деяких випадках в інтересах довірителя конфлікт може бути корисний як для припинення утисків прав свідка та вибудовування подальших психологічних взаємин зі слідчим, так і для отримання від нього в процесі суперечки інформації про його подальші наміри щодо свідка [7].

Під час допиту свідка адвокат має стежити за тим, чи дотримується слідчий тривалості його проведення. Відповідно до ч. 2 ст. 224 КПК, допит не може продовжуватися без перерви понад дві годин, а в цілому - понад вісім годин. Якщо провадиться допит малолітньої або неповнолітньої особи, він не може продовжуватися без перерви понад одну годину, а загалом понад дві години [4]. Якщо час проведення допиту свідка слідчим не дотриманий, адвокат повинен висловити зауваження, яке підлягає занесенню слідчим до протоколу слідчої (розшукової) дії. За певних обставин адвокат під час судового розгляду може заявити клопотання про визнання показань свідка недопустимими відповідно до ст. 86 КПК через порушення вимог щодо тривалості його допиту [6, с. 128].

Після завершення допиту дуже важливо ретельно вичитати підготовлений слідчим протокол, у разі потреби внести в нього коригування та доповнення. У разі, коли слідчий відмовляється вносити дані зміни і доповнення, слід твердо наполягати на цьому, оскільки доказом у кримінальному провадженні будуть саме фактичні дані, які містяться у протоколі слідчої (розшукової) дії. Саме тому так важливо, щоб протокол містив усі ті відомості, які, на переконання адвоката, $є$ важливими в інтересах довірителя.

Після закінчення допиту адвокат повинен вжити заходів щодо отримання підсумкового тексту показань. 3 цією метою він може попросити у слідчого копію протоколу допиту; зафіксувати хід допиту з допомогою звуко- відеозапису. Наявність у адвоката та у свідка письмового тексту показань має надзвичайно велике значення, оскільки надалі, у разі повторного виклику свідка на допит, а тим більше можливого притягнення його до кримінальної відповідальності у цьому кримінальному провадженні, даний документ значно полегшить підготовку до допиту у статусі підозрюваного, обвинуваченого.

Варто також згадати про інші процесуальні можливості адвоката. Зокрема, за змістом п. 7 ст. 64-1 КПК України, представляючи інтереси юридичної особи, щодо якої здійснюється провадження, адвокат може заявляти клопотання про проведення процесуальних дій [4]. 
У таких випадках необхідна ретельна попередня оцінка доказової цінності інформації, яка може бути отримана за клопотанням адвоката. Перш ніж клопотати про проведення допиту певної особи, адвокату слід спрогнозувати, які показання вона може дати, щоб не погіршити становище довірителя. На це може вказати й сам клієнт, однак зазвичай професійний адвокат повинен проявляти необхідну активність у кримінальному провадженні, виявляти достатню тактичну гнучкість, виходячи з інтересів свого клієнта.

\section{Висновок}

Отже, доходимо висновку про важливість фактичних даних, отриманих шляхом допиту свідка під час досудового розслідування, за допомогою яких визначаються напрями подальшого розслідування, з'ясовуються окремі факти про подію та інші обставини кримінального правопорушення, характер дій кожного співучасника, дані, що мають тактичне значення тощо. Незважаючи на те, що сам по собі допит може зайняти відносно нетривалий час, обсяг завдань, які повинен для себе ставити і надалі вирішувати для свого довірителя адвокат, вельми значний, що свідчить про значимість виконуваної роботи для клієнта у кримінальному провадженні. Надзвичайно важливим при цьому є знання та вміле застосування адвокатом тактичних прийомів, спрямованих на встановлення належного контакту не тільки з підзахисним, а й з уповноваженою особою, яка проводить вказану слідчу (розшукову) дію.

\section{Список використаних джерел:}

1. Горб Ю. В. Проблемні аспекти процесу збирання доказів стороною захисту на етапі досудового провадження. URL: http://legalactivity. com.ua/index.php?option $=$ com_content $\&$ view $=$ a rticle \&id $=1657 \% 3$ A04101715\& ${ }^{-}$atid $=195 \% 3$ A510 $2017 \&$ Itemid $=241 \&$ lang $=$ enhttp://legalactivity. com.ua/index.php?option $=$ com_content $\&$ view $=$ a rticle $\&$ id $=1657 \% 3 \mathrm{~A} 041017-15 \&$ catid $=195 \% 3 \mathrm{~A} 5$ $102017 \&$ Itemid=241\&lang=en. (дата звернення: 26.07.2019)

2. Баев М. О. Тактические основы деятельности адвоката-защитника в уголовном судопроизводстве России: Теория и практика : дис. ... д-ра юрид. наук: 12.00.09. Воронеж, 2006. 401 с.

3. Пронькина А. Н. Ошибки адвокатов-защитников в уголовном судопроизводстве : дис. ... канд юрид. наук: 12.00.09. Воронеж, 2006. 231 с.

4. Кримінальний процесуальний кодекс України : Закон України від 12.04.2012 № 4651-VI. URL: https://zakon.rada.gov.ua/go/4651-17. (дата звернення: 26.07.2019).

5. Лань О. Ю. Захисник як суб'єкт доказування у досудовому розслідуванні кримінальних проваджень щодо неповнолітніх. Київ, 2016. 223 с.

6. Панчук О. В. Надання свідку правової допомоги у кримінальному процесі : автореф. дис ... канд. юрид. наук: 12.00.09. Київ, 2013. 226 с.

7. О работе адвоката при допросе свидетеля по уголовному делу. URL: https://zakon.ru/ blog/2018/5/4/o_rabote_advokata_pri_doprose svidetelya_p_ugolovnomu_delu. (дата звернення: 26.07.2019).

8. Бахин В. П., Когамов М. Ч., Карпов Н. С. Допрос на предварительном следствии (уголовно-процессуальные и криминалистические вопросы). Алматы, 1999. 208 с.

The scientific article focuses on the role and place of the lawyer during the interrogation of the witness, the tactical and organizational peculiarities of his activity highlighted, aimed at preparing for the interrogation of the witness and for participating in obtaining his testimony at the stage of pre-trial investigation. Separate reasons for the improper level of legal aid are singled out, proposals are made to improve the activity of the lawyer in this direction. It is determined that the position of the lawyer and his client in the criminal proceedings should be aimed at minimizing the possible risks for the interviewee, and therefore in the course of preparation, the lawyer puts himself in the investigator's place, finding weak points in his position, and then explains them to the client. It was found out that during the development of a common position and the simultaneous consulting of the client, the lawyer should foresee any options for the development of the questioning, discuss them carefully with the client, so that he would be ready to give clear answers to any question of the investigator and respond to the latter's actions as planned at the preparatory stage. It is proved that having a lawyer and a witness to testify in writing is extremely important, since in the future, if the witness is re-summoned for questioning, and even more likely to bring him to justice in this criminal proceeding, this document will greatly facilitate the preparation for questioning in the status of the suspect, the accused. It is emphasized on the considerable amount of tasks that the lawyer should set for himself and further to solve for his principal, which testifies to the importance of the work performed for the client in criminal proceedings. Extremely important, at the same time, is the knowledge and skillful use by the lawyer of tactical techniques aimed at establishing proper contact not only with the client, but also with the authorized person who conducts the investigative (investigative) action. It is concluded that the importance of the evidence obtained through the examination of a witness during the pre-trial investigation, which determines the directions of further investigation, clarifies the individual facts about the event and other circumstances of the criminal offense, the nature of the actions of each accomplice, data of tactical importance, etc.

Key words: pre-trial investigation, witness examination, testimony, lawyer, petition, tactical receptions. 